\title{
PEAK PlasmaBlade and coblation adenotonsillectomy: Report of 2 cases and literature review
}

\section{PEAK PlasmaBlade ve koblasyon adenotyonsillektomisi: íki olgu raporu ve literatürün gözden geçirilmesi}

\author{
Darshini NAGARAJAH, Vengatesh Rao APPANNAN, Norhafiza Mat LAZiM, Baharudin ABDULLAH
}

\section{ABSTRACT}

Adenotonsillectomy is one of the most frequently performed surgeries by otorhinolaryngologists worldwide. Coblation and PEAK surgery systems are new techniques of surgery that revolutionize the way surgery is performed today. We report our experience with two patients being treated with the combined techniques of adenotonsillectomy using both coblation and PEAK PlasmaBlade technologies.

Keywords: Adenotonsillectomy, coblation, PEAK PlasmaBlade öz

Dünya ölçeğinde adenotonsillektomi KBB uzmanlarınca en sık uygulanan ameliyatlardan biridir. Koblasyon ve PEAK cerrahi sistemleri bugünlerde uygulanan cerrahilerde devrim yaratan yeni bir tekniktir. Hem koblasyon hem de PEAK PlasmaBlade teknolojisi kombinasyonuyla gerçekleştirilen adenotonsillektomi ile tedavi edilmiş iki hastaya ilişkin deneyimlerimizi bildiriyoruz.

Anahtar kelimeler: Adenotonsillektomi, koblasyon, PEAK PlasmaBlade

postoperative pain and bleeding complications ${ }^{3}$. Adenotonsillectomy are being performed using cold dissection, guillotine technique, laser, bipolar and monopolar cautery, harmonic scalpel, PEAK (pulsed electron avalanche knife) PlasmaBlade and coblation. We report our use of PEAK PlasmaBlade and coblation technique in two children.

\section{CASE REPORT}

Two children aged 6 , and 8 years underwent adenotonsillectomy using both coblation and PEAK PlasmaBlade techniques. The patients underwent coblation tonsillectomy on the right side while PEAK PlasmaBlade tonsillectomy was done on the left side. For adenoidectomy, only PEAK plasma technique was used. The procedure for both techniques was almost similar to conventional surgery except for the usage raoperative hemostasis as well as minimization of 
Table 1. Intraoperative blood loss and duration of surgery (right tonsillectomy done by coblation while left tonsillectomy was done by PEAK plasma blade).

\begin{tabular}{lllll}
\hline & Age/Sex & Presenting symptoms and duration & Intraoperative blood loss & Duration of procedure \\
\hline Patient 1 & 6/Female & $\begin{array}{l}\text { Recurrent sore throat with snoring } \\
\text { and nasal block for } 3 \text { years }\end{array}$ & $<50 \mathrm{ml}$ (both sides) + adenoidectomy & $29 \mathrm{minutes}$ \\
Patient 2 & 8/Male & Loud snoring for 3 years & $<50 \mathrm{ml}$ (both sides) + adenoidectomy & 37 minutes \\
\hline
\end{tabular}

of specialized instruments. Both patients were intubated per orally. For coblation tonsillectomy, EVAC 70 hand piece (Smith \& Nephew) was used and the right tonsil was dissected from upper pole to lower pole with power setting for cutting at $7 \mathrm{~W}$ and coagulation at 3W. PEAK PlasmaBlade surgery system consists of PEAK PlasmaBlade dissection device and the PULSAR II Generator (Medtronics). The PEAK PlasmaBlade device was used for dissecting the left tonsil from upper pole to lower pole with power setting for cutting at $1 \mathrm{~W}$ and coagulation at $4 \mathrm{~W}$. For adenoidectomy, PEAK plasma surgery system was used and adenoid was removed by dissecting from upper part to lower part of adenoid with power setting for cutting at $1 \mathrm{~W}$ and coagulation at $8 \mathrm{~W}$.

Perioperative blood loss was estimated to be less than $50 \mathrm{ml}$ for both techniques intraoperatively (Table 1). The median operation time was 7.5 minutes for the right(coblation) and 17 minutes for the left tonsillectomies (PEAK plasma). Median operation time for adenoidectomy was 3 minutes for both cases.

The median VAS (Visual Analogue Scale) pain score on the first day was $5 / 10$ and subsequently reduced to $2 / 10$ over a week (Figure 1 ). Postoperatively there was no request for analgesics from both patients. Both patients were discharged well on the first postoperative day without any complications. They were able to consume soft diet prior to discharge. During our follow-up period, there were no major or minor complications noted for both coblation and PEAK plasma techniques. The median time to return to normal diet for both children was about 7.5 days. Oropharyngeal examination at postoperative 1. week demonstrated only minimal slough tissue of both tonsillar fossa mainly at inferior part of tonsillar fossa for both patients. Otherwise there was no traces of fresh blood or clots seen.

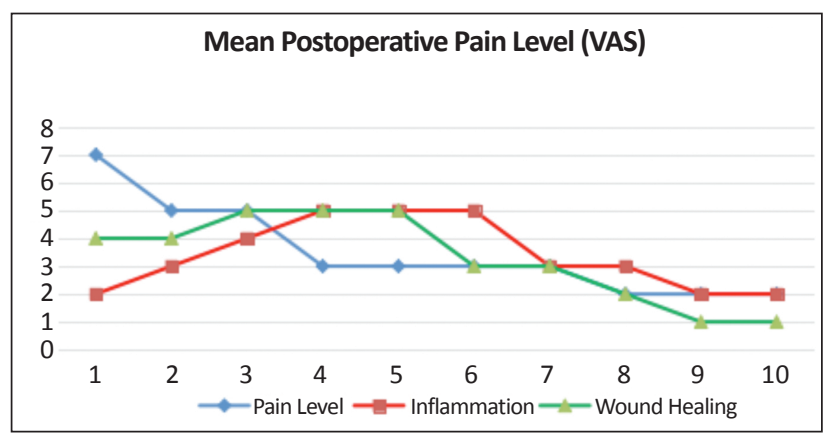

Figure 1. Post operation pain, inflammation period and wound healing.

\section{DISCUSSION}

Result of a survey had showed that $16 \%$ of practicing pediatric otolaryngologists in US favour the use of coblation for tonsillectomy ${ }^{3}$. Reduced intraoperative time and blood loss in coblation tonsillectomy has been shown as compared to cold dissection tonsillectomy ${ }^{4}$. Coblation technology uses less energy to cut soft tissue resulting in cooler temperature during surgical excision ${ }^{5}$. The use of coblation for tonsillectomy may gain more support with the availability of better devices and with more trained surgeons.

The PEAK PlasmaBlade is a unique soft tissue dissection instrument that uses less energy during cutting of tissue as compared to traditional cautery method. Thus, it operates at lower temperatures which result in less postoperative pain. Peak PlasmaBlade approach has made a significant difference in that it decreased thermal injury profile which avoids inflammatory response and helps in rapid wound healing ${ }^{6}$. PEAK PlasmaBlade has an average operating temperature of $40-170^{\circ} \mathrm{C}$ when used during surgery. 
The zone of thermal injury in PEAK PlasmaBlade incision $(0.6 \mathrm{~cm})$ was significantly smaller when compared to electrosurgical cut or coagulation incisions $(4 \mathrm{~cm})^{6}$. Thus, PEAK PlasmaBlade can be used nearby critical structures with lesser risk of vascular injury. In contrast, the average operating temperature for coblation technique was $40-70^{\circ} \mathrm{C}$. As for coblation technique, the surgical ablation of the tissues is performed without inducing additional collateral tissue necrosis which could be a reason for its popular use in the field of otolaryngology.

When comparing coblation and traditional techniques, surgeons detected hemorrhage with tissue damage in $1 \%$ of the patients, and early postoperative recovery for coblation technique ${ }^{7}$. In another study, coblation tonsillectomy had shown a drastic decrease in postoperative pain comparing with conventional technique ${ }^{8,9}$. As for PEAK PlasmaBlade versus conventional surgery, one study showed significant reduction in thermal injury and improved wound strength and histology with better visual assesment of scars ${ }^{6}$. It has been shown that PEAK PlasmaBlade reduces level of inflammation, thus leading to good epithelization resulting in improved healing and cosmesis $^{10-12}$.

An online survey among members of American Society of Pediatric Otolaryngology showed a changing trend towards using monopolar cautery and coblation for pediatric adenotonsillectomy ${ }^{13}$. However, it has been shown that there is a tendency for less pain and decreased operating time in coblation group as compared to monopolar cautery ${ }^{14}$. Furthermore, the use of monopolar cautery has been shown to have higher risk of haemorrhage especially with the use of increased power ${ }^{15}$.

In paediatric adenotonsillectomy, postoperative pain should be minimized so as to encourage children to switch to oral intake as soon as possible. Both coblation and PEAK PlasmaBlade had been shown to achieve this objective ${ }^{16-18}$. To further minimize postoperative pain and prevent postoperative haemorrhage, coablation intracapsular tonsillectomy has been advocated. There has been limited evidence to determine that intracapsular tonsillectomy is better than extracapsular tonsillectomy. Duarte et al. ${ }^{19}$ found both hemorrhage and pain relief much better in the intracapsular coblation technique as compared to extracapsular technique. However, another study by Reusser et al. ${ }^{20}$ contradicted this finding. Therefore, further studies are required to determine the benefits of performing intracapsular tonsillectomy as compared to extracapsular tonsillectomy.

In conclusion, we found that there were no differences in intraoperative blood loss, postoperative pain, and time needed to regain normal diet and daily activity for both techniques. Coblation technology has lesser operating time than PEAK PlasmaBlade technique which could be due to our surgeon's familiarity with it. There were also no postoperative hemorrhages in both technologies.

All authors declared no conflict of interest.

\section{REFERENCES}

1. Spektor Z, Kay DJ, Mandell DL. Prospective comparative study of pulsed-electron avalanche knife (PEAK) and bipolar radiofrequency ablation (coblation) pediatric tonsillectomy and adenoidectomy. Am J Otolaryngol. 2016;37:528-33. https://doi.org/10.1016/j.amjoto.2016.08.003

2. Izny Hafiz Z, Rosdan S, Mohd Khairi MD. Coblation tonsillectomy versus dissection tonsillectomy: a comparison of intraoperative time, intraoperative blood loss and post-operative pain. Med J Malaysia. 2014;69:74-8.

3. Shah UK. What surgeons want in a tonsillectomy instrument: survey of American Society of Pediatric Otolaryngology members. Annu Meet Am Soc Pediatr Otolaryngol, Chicago, May 2006.

4. Shapiro NL, Bhattacharyya N. Cold dissection versus coblation assisted adenotonsillectomy in children. Laryngoscope. 2007;117:406-10. https://doi.org/10.1097/MLG.0b013e31802ffe47

5. Omrani M, Barati B, Omidifar N, Okhovvat AR, Hashemi SA. Coblation versus traditional tonsillectomy: $A$ double blind randomized controlled trial. J Res Med Sci. 2012;17:45-50.

6. Loh SA, Carlson GA, Chang EI, Huang E, Palanker D, Gurtner GC. Comparative healing of surgical incisions created by the PEAK Plasma Blade, conventional electrosurgery and a scalpel. Plast Reconstr Surg. 2009;124:1849-59. https://doi.org/10.1097/PRS.0b013e3181bcee87

7. Lee KC, Altenau MM, Barnes DR, Bernstein JM, Bikhazi NB, Brettscheider FA, Caplan CH, Ditkowsky WA, Ingber CF, Klausner LM, Moghaddassi MM. Incidence of complications for subtotal ionized field ablation of the tonsils. Otolaryngology Head Neck Surg. 2002;127:531-8. 
https://doi.org/10.1067/mhn.2002.129736

8. Shah UK, Galinkin J, Chiavacci R, Briggs M. Tonsillectomy by means of plasma-mediated ablation: prospective, randomized, blinded comparison with monopolar electrosurgery. Arch Otolaryngol Head Neck Surg. 2002;128:672-6. https://doi.org/10.1001/archotol.128.6.672

9. Philpott CM, Wild DC, Mehta D, Daniel M, Banerjee AR. A double-blinded randomized controlled trial of coblation versus conventional dissection tonsillectomy on post-operative symptoms. Clin Otolaryngol. 2005;30:143-8. https://doi.org/10.1111/j.1365-2273.2004.00953.x

10. Bettinger DA, Yager DR, Diegelmann RF, Cohen IK. The effect of TGF-beta on keloid fibroblast proliferation and collagen synthesis. Plast Reconstr Surg. 1996;98:827-33. https://doi.org/10.1097/00006534-199610000-00012

11. Border WA, Noble NA. Transforming growth factor beta in tissue fibrosis. N Engl J Med. 1994;331:1286-92. https://doi.org/10.1056/NEJM199411103311907

12. Martin P. Wound healing-aiming for perfect skin regeneration. Science. 1997;276:75-81. https://doi.org/10.1126/science.276.5309.75

13. Walner DL, Mularczyk C, Sweis A. Utilization and trends in surgical instrument use in pediatric adenotonsillectomy. Int J Pediatr Otorhinolaryngol. 2017;100:8-13. https://doi.org/10.1016/j.ijporl.2017.06.019

14. Metcalfe C, Muzaffar J, Daultrey C, Coulson C. Coblation ton- sillectomy: a systematic review and descriptive analysis. Eur Arch Otorhinolaryngol. 2017;274:2637-47. https://doi.org/10.1007/s00405-017-4529-4

15. Blanchford H, Lowe D. Cold versus hot tonsillectomy: state of the art and recommendations. ORL J Otorhinolaryngol Relat Spec. 2013;75:136-41. https://doi.org/10.1159/000342315

16. Pynnonen M, Brinkmeier JV, Thorne MC, Chong LY, Burton MJ. Cochrane Database Syst Rev. 2017; 8: CD004619. Coblation versus other surgical techniques for tonsillectomy.

17. Gustavii N, Bove M, Dahlin C. Postoperative morbidity in traditional versus coblation tonsillectomy. Ann Otol Rhinol Laryngol. 2010;119:755-60.

18. Yilmazer R, Yazici ZM, Balta M, Erdim I, Erdur O, Kayhan FT. PlasmaBlade vs. cold dissection tonsillectomy: A prospective, randomized, double-blind, controlled study in adults. Ear Nose Throat J. 2017;96:250-6.

19. Duarte VM, Liu YF, Shapiro NL. Coblation total tonsillectomy and adenoidectomy versus coblation partial intracapsular tonsillectomy and adenoidectomy in children. Laryngoscope. 2014;124:1959-64.

https://doi.org/10.1002/lary.24632

20. Reusser NM, Bender RW, Agrawal NA, Albright JT, Duncan NO, Edmonds JL. Post-tonsillectomy hemorrhage rates in children compared by surgical technique. Ear Nose Throat J. 2017;96:E7-E11. 